\title{
Posisi Indonesia di Tengah Fenomena Korporasi Global (Studi Kasus: Relasi Dagang Indonesia - Toyota Pasca Kesepakatan IJEPA)
}

\author{
Aspin Nur Arifin Rivai \\ Universitas Indonesia
}

\begin{abstract}
This study aims to understand and examine the economic relation between Indonesia and Japan. This paper questioned; how will the degree of Indonesia's economic dependence on Toyota's corporation affect the economic diplomacy through IJEPA? As analytical tools, this article used the concept of transnational economic diplomacy. This paper argues that Indonesia has experienced a very high economic dependency phase in the automotive sector, through Toyota Corporation. This dependence is not only on the existing corporation, but also on the partner country - Japan. Meanwhile, amidst the existing dependencies, the IJEPA agreement itself contains a major problem. It is seen that Japan's offer through MIDEC program in the form of technology transfer has not yet shown its seriousness. As a result, negotiating agreements to implementation is considered a failure. The two findings are alternating to make Indonesia lower in the bargaining position of the next negotiation.
\end{abstract}

Keywords: Transnational economic diplomacy, economic dependency, IJEPA, MIDEC, and Toyota.

\begin{abstract}
Abstrak
Tulisan ini bertujuan memahami dan membahas hubungan ekonomi antara Indonesia dan Jepang. Tulisan ini mempertanyakan; bagaimana tingkat ketergantungan ekonomi Indonesia terhadap perusahaan Toyota mempengaruhi diplomasi ekonomi melalui IJEPA? Untuk alat analisis, tulisan ini menggunakan konsep diplomasi ekonomi transnasional. Tulisan ini berpendapat bahwa Indonesia mengalami ketergantungan ekonomi yang sangat tinggi di sektor ekonomi, melalui perusahaan Toyota. Ketergantungan ini tidak hanya terhadap perusahaan, tetapi juga terhadap Jepang sebagai sebuah negara. Sementara itu, di tengah ketergantungan tersebut, kesepakatan IJEPA memiliki beberapa masalah. Diketahui bahwa tawaran Jepang melalui program MIDEC dalam bentuk transfer teknologi belum menunjukkan keseriusan. Alhasil, negosiasi kesepakatan untuk mengimplementasikannya dapat dianggap sebagai kegagalan. Tulisan ini menemukan dua hal terkait alternatif kebijakan untuk meningkatkan posisi tawar Indonesia di kesepakatan selanjutnya.
\end{abstract}

Kata-kata kunci: Diplomasi ekonomi transnasional, ketergantungan ekonomi, IJEPA, MIDEC, Toyota 


\section{Pendahuluan}

Kekelaman Perang Dunia (PD) 2 yang dialami oleh Jepang, lambat laun bangkit dan mengemudikan kepentingan ekonomi dan perdagangan sebagai upaya pembangunan. Penelitian Ye Hao menyebut diplomasi ekonomi kontemporer sejatinya dikenalkan oleh Jepang (Hao, 2013). Fokus utama Jepang setelah PD 2 ialah menjadikan agenda ekonomi sebagai ihwal utama. Pada pertengahan 1950-an terjadi peningkatan dan pertumbuhan pesat oleh besarnya permintaan sumber daya dan pasar saat itu. Hao memandang penguatan diplomasi ekonomi Jepang mengalami penguatan institusi domestik di bawah pemerintahan Nobusuke Kishi, dimana diplomasi ekonomi mulai diimplementasikan pada relasi dengan negara-negara di Asia Tenggara.

Konstelasi dan dinamika politik global dalam fase Perang Dingin kemudian ditangkap sebagai serangkaian momen penting. Semenjak dimensi ekonomi mendapat legitimasi utuh pada usaha diplomasi, maka berimplikasi pada penguatan aktor baru. Susan Strange menyebut aktor non-negara seperti korporasi dan perusahaan sama pentingnya dengan aktor negara. Strange dengan simplistis menyebut kehadiran aktor nonnegara dalam diplomasi ekonomi telah memunculkan model baru yaitu "triangular diplomacy" (Strange, 2004).

Perubahan signifikan yang dialami Jepang pada tahun 1970-an atau dikenal sebagai keajaiban Asia Timur, justru kemakmuran tersebut telah mengabaikan kepentingan negara berkembang saat itu. Persisnya, Jepang dituduh sebagai negara "animal economic" - yaitu hanya memikirkan bagaimana cara memperoleh keuntungan yang semaksimalnya, namun merugikan negara mitranya. Sikap emoh yang dilakukan oleh negara mitranya seperti Korea Selatan, Thailand, dan termasuk Indonesia mengundang resistensi oleh masyarakat sipil yaitu tahun 1973-1974. Di Indonesia sendiri dikenal dengan peristiwa Malari (Malapetaka Lima Belas Januari).

Dalam momen resistensi yang dialami oleh Jepang, maka diplomasi ekonomi Jepang mengalami perubahan signifikan. Untuk membangun kembali kepercayaan kepada negara mitranya seperti Indonesia, Jepang mengkonsentrasikan pemberian bantuan untuk program pengembangan yang dikenal sebagai Official Development Assistance (ODA), salah satunya sektor teknologi otomotif. Perlu diingat, hubungan diplomatik antara Indonesia dengan Jepang telah memasuki usia 57 tahun sejak kerjasama tahun 1958. Pada tahun 2016, total unit produksi di Indonesia mencapai 1.172.968, sedangkan pesaingnya dari negeri yang sama yaitu Daihatsu hanya menggapai produksi sebesar 537.415. Angka diatas menunjukkan porsi produksi di Indonesia sangat tinggi. Meskipun angka tersebut dipandang telah menyerap lapangan pekerjaan yang tidak sedikit, namun untuk urusan produksi sendiri, hampir kebanyakan produk Toyata di 
Indonesia hanya dalam bentuk perakitan semata ${ }^{1}$. Sementra itu, tingginya produksi dalam negeri, tidak selaras dengan meningkatnya nilai ekspor Toyota Indonesia. Di bandingkan dengan negara lain seperti Thailand, negara ini turut serta memproduksi berbagai produk Toyota. Tahun 2010, Thailand telah memproduksi mobil 1.644 .513 unit, dan penjualan 800.357 unit. Nilai ekspor pada tahun tersebut sebesar $18.7 \%$, sedangkan impor yang hanya $8.54 \%$. Perbandingannya dengan Indonesia, di Tahun yang sama, Indonesia hanya mendapat nilai ekspor $2.55 \%$, dan impor yang timpang yaitu 5.56\% (Doner \& Wad, 2014).

Di sisi lain, Indonesia sebagai produsen domestik untuk produk Toyota tertentu, tetapi Indonesia mendapat kerugian akibat meningkatnya harga jual di pasar domestik dalam negeri. Sebagai ilustrasi dari kondisi ini, pada tahun 2008 konsumen untuk membeli mobil SUV Toyota cukup dengan US\$28.000. bila dengan kurs Rp10.200, harga sebuah SUV tersbeut sekitar Rp280-an juta. Saat sekarang untuk membeli mobil yang sama perlu lebih dari US\$40.00, setara Rp540 juta dengan asumsi kurs Rp13.500. Artinya dalam kurun sembilan tahun (2008-2017) harus membayar lebih mahal sekitar US\$12.000 atau Rp162 juta. Padahal bila menilik kandungan lokal rata-rata meningkat, harga mobil Toyota seharusnya turun karena tidak ada perubahan fiskal.

Potret kerjasama yang patut dikritisi selanjutnya ialah kerjasama Indonesia Japan Economic Partnerships (IJEPA). Skema perdagangan yang ditanda-tangani tahun 2008, dipandang sebagai jalan menguatkan hubungan diplomatik antara kedua negara. Posisi Indonesia menaruh ketertarikan, salah satunya bidang indusri otomotif. Dalam poin otomotif, Indonesia berkepentingan memuat kemandirian teknologi oleh tawaran Jepang dengan skema MIDEC (Manufacturing Industry Development Center). Akan tetapi, setelah penandatanganan kerjasama ini, Indonesia belum mendapat keuntungan dari harapan sebelumnya. Pada dasarnya IJEPA memuat aturan perdagangan dimana tarif preferensi umum (PTA) dengan skema sekitar 35\% pos tarif bea masuk Indonesia akan diturunkan menjadi $0 \%$, sedangkan Jepang menurunkan sekitar $80 \%$ pos tarifnya.

Di tengah geliat kekuatan Jepang dalam pasar otomotif Indonesia, lambat laun upaya program MIDEC mengalami stagnansi akibat daya saing industri masih lemah. Impian Indonesia melalui skema MIDEC sendiri

${ }^{1}$ PT. Toyota Motor Manufacturing Indonesia adalah perusahaan yang bertanggung jawab memproduksi jenis mobil Toyota di Indonesia. Pada tahun 2013, perusahaan inin telah memproduksi, yaitu: Toyota Kijang Innova pada segemn MPV, Toyota Fortuner pada segmen SUV, dan Toyota Etios pada segmen sedan kecil. Dari kesemua produk tersebut tidak memperlihatkan totalitas produksi mandiri, sebab Indonesia hanya mendapat legitimasi pembuatan yang sifatnya hard-materials, yaitu; Stamping, Casting, Packing, dan Vanning, sedangkan desain dan teknologi tetap berasal dari Jepang. 
dianggap sebagai upaya kemandirian teknologi untuk mengembalikan program mobil nasional. Sayangnya, pertukaran pengetahuan dan teknologi yang dilakukan oleh pihak Jepang belum sepenuhnya berjalan. Artinya, kerjasama kemitraan yang dilakukan oleh Indonesia dengan Jepang dan korporasinya mengalami problem.

Dalam konteks tertentu, diplomasi ekonomi sejatinya mengatasi empat resiko besar; resiko fiskal, resiko moneter, resiko industrial, dan resiko lapangan kerja. Jika bayang-bayang ketergantungan yang tinggi, maka ancaman Indonesia mendapat empat resiko tersebut. Terlebih, Indonesia menempatkan produksi otomotif domestik menjadi bagian dari sepuluh produk unggulan dalam perdagangan global, padahal produksi otomotif tersebut bukan sebagai produk mobil nasional. Hal ini tentu saja menghawatirkan di hari esok, apalagi model kerjasama yang dibangun oleh Indonesia ke mitra diplmoasinya justru memanjakan imortir yang ada. Paper ini kemudian mempertanyakan; sejauh mana dependensi ekonomi Indonesia terhadap korporasi Toyota yang akan mempengaruhi posisi tawar dalam diplomasi ekonomi melalui IJEPA? Sementara itu, dalam metode penelitian paper ini berkutat pada pola pemikiran deduktif secara intensif, sedangkan tipe penilitian relatif adalah eksplanatif. Data akan berbentuk data sekunder dan data primer. Data sekunder meliputi penggunaan referensi dari buku, jurnal dan artikel, konten website, dll. Sedangkan data primer merupakan data-data perdagangan dan investasi. Penarikan kesimpulan penelitian dilakukan dengan cara menganalisa hasil temuan, dengan menggunakan kerangka konseptual yang dibangun sebelumnya.

\section{Diplomasi Ekonomi Transnasional}

Kajian diplomasi ekonomi moderen memuat berbagai irisan besar. Awalnya diplomasi hanya menempatkan negara sebagai pelaku penting dalam interaksi dunia. Lambat laun implikasi dari berbagai isu global memberi legitimasi aktor non-negara turut memainkan peranan penting, utamanya korporasi. Perubahan signifikan ini ditandai oleh wacana "ekonomi" yang mengarah ke orientasi high-politics pasca PD 2. Bahkan, dimensi ekonomi menjadi wahana penting setelah Perang Dingin, yang disebut-sebut sebagai momentum multilateralisme.

Dalam definisinya, diplomasi ekonomi sendiri belum mengalami kebakuan. Hal ini disebabkan oleh aktifitas yang seringkali mengalami perubahan, baik dalam segi aktor, cakupan, dan aktifitasnya. Rashid mendefinisikan diplomasi ekonomi sebagai proses formulasi dan negosiasi kebijakan yang berkaitan dengan kegiatan produksi, pertukaran barang, jasa, tenaga kerja dan investasi di negara lain (Rashid, 2005). Odell menawarkan definisi yang lebih luas dengan memasukkan elemen lain yakni adanya kebijakan terkait pertukaran uang dan informasi termasuk bantuan luar negeri atau official development assistance (Odell, 2000). 
Dalam pemahaman ini, diplomasi ekonomi kemudian menjadi senjata penting bagi negara-negara untuk dapat bekerjasama ataupun berkonflik di sistem internasional. Menurut van Bergeijk \& Moons, diplomasi ekonomi mengandung tiga elemen, yakni (Bergeijk \& Moons, 2007: 2): (1) Penggunaan pengaruh dan hubungan politik untuk mempromosikan dan/ atau mempengaruhi perdagangan dan investasi. (2) Pemanfaatan aset-aset ekonomi untuk meningkatkan biaya konflik dan memperkuat hubungan yang saling menguntungkan. (3) Upaya untuk mengkonsolidasikan iklim politik dan lingkungan internasional untuk mencapai tujuan-tujuan ini.

Pada dasarnya diplomasi ekonomi transnasional memuat aktor baru yaitu negara dengan korporasi. Meskipun pola relasi ini hanya memainkan dua aktor, tetapi realitasnya tetap melibatkan negara dengan negara. Artinya kehadiran aktor transnasional membutuhkan negara asal korporasi. Selain itu, diplomasi jenis ini turut memainkan aktor-aktor lain seperti perusahaan-perusahaan domestik (host country), pelaku bisnis, media, asosiasi lokal. Pada dasarnya diplomasi ekonomi (ataupun transnasional) suatu negara dapat dilakukan dengan baik apabila pemerintah dapat menyeimbangkan antara kepentingan nasional dengan strategi kebijakan luar negerinya, bahkan perlu dilakukan pengelolaan dan penyelidikan yang saling berkaitan dalam diplomasi untuk melihat potensi negara (OkanoHeijmans, 2013: 33).

Dalam pandangan Nicholas Bayne dan Stephen Woolcock memaparkan bahwa terdapat tiga faktor pendorong diplomasi ekonomi yaitu, keadaan politik dan ekonomi suatu negara, negara dan aktor negara, dan public dan swasta (Bayne \& Woolcock, 2011: 3-4). Keberlangsungan aktor selain negara yaitu korporasi dipandang penting untuk memahami diplomasi ekonomi saat ini. pada dasarnya, korporasi sifatnya borderless, yaitu menjangkau setiap negara yang mereka butuhkan. Meskipun sifatnya tanpa batas, relasi antara korporasi dengan negara dianggap relevan untuk dijelaskan dalam diplomasi ekonomi. Penulis memandang klasifikasi tersebut sebagai konsep diplomasi ekonomi transnasional. Bahkan dalam ritus diplomasi ekonomi transnasional tidak hanya memperlihatkan relasi state to business, melainkan mengikut-sertakan berbagai aktor non negara seperti perusahaan swasta di home-country maupun host country. Raymond Saner dan Lichia Yiu menyebut kondisi tersebut memperlihatkan berbagai aktor yang bermain dalam diplomasi ekonomi telah mengarah pada momentum posmoderen (Saner \& Yiu, 2003). Dalam aktor non-negara yang berperan dalam diplomasi ekonomi antara lain, perusahaan-perusahaan yang ikut dalam interaksi ekonomi, pelaku bisnis, NGO, media, asosiasi lokal, dan lain sebagainya. Saner dan Yiu menyampaikannya dalam sebuah relasi yang lebih simplistis, yaitu: 


\section{Gambar 1. Konsep Diplomasi Ekonomi}

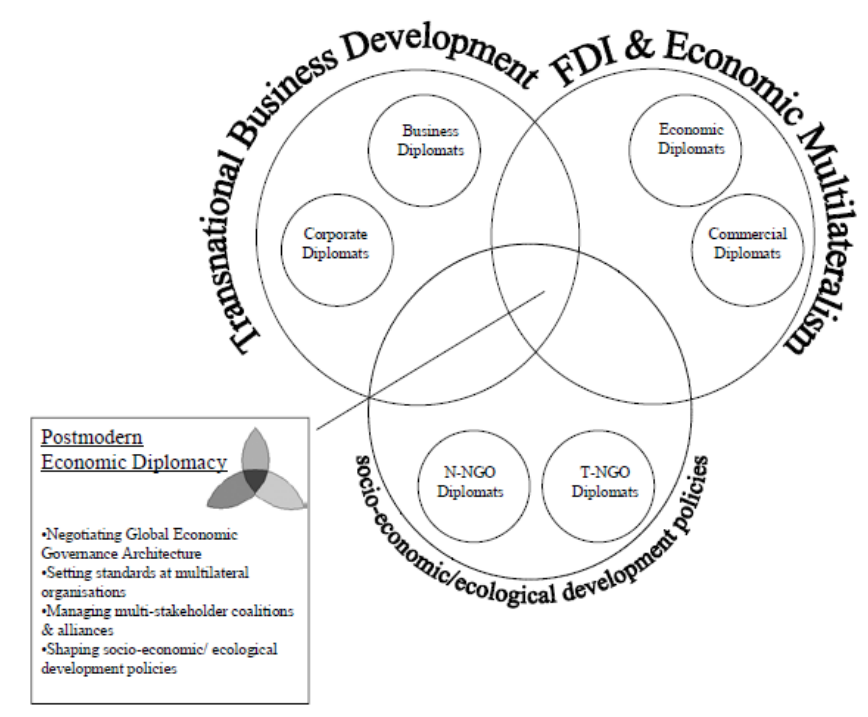

Tulisan ini menggunakan konsep diplomasi ekonomi transnasional terbagi menjadi dua kategori yaitu: (1) Kegiatan diplomasi ekonomi pada perdagangan internasional. (2) Instrumen untuk memahami tujuan kepentingan aktor lain yang menyangkut nilai komersial dan politik dalam suatu arena tertentu dimana diplomasi ekonomi dibentuk dan diimplementasikan.

\section{IJEPA: Kegagalan Diplomasi Ekonomi?}

Diplomasi ekonomi Jepang ke berbagai negara, termasuk ke Indonesia dikenal dengan skema Economic Partnership Agreement (EPA). Bagi Jepang, EPA dianggap sebagai orientasi kerjasama untuk menghindari ketimpangan yang ada dalam kemitraan bilateral. Dalam hal ini, EPA berbeda dengan Free Trade Area (FTA). ${ }^{2}$ Bagi Jepang, EPA merupakan perjanjian kerjasama perdagangan dan investasi. Dalam kesepakatan tersebut turut diatur tentang penurunan tarif yang biasanya terdapat tarif Most Favoured Nation (MFN) bagi negara anggota WTO dalam model FTA. Akan tetapi, skema EPA mengikuti kesepakatan penghapusan tarif antara negara mitra. Implementasi EPA dalam persaingan pasar sejatinya harus memuat unsur fundamental, yaitu: pembangunan dan pengembangan

\footnotetext{
${ }^{2}$ Sebagai perbandingan sederhana antara FTA dengan PTA, yaitu FTA: penghapusan tariff yang dibebankan oleh negara (liberalisasi perdagangan pada kawasan tersebut), sedangkan PTA mengikuti pengahapusan tariff bersamaan dengan kerjasama di berbagai bidang. Selain itu, FTA mengatur penghapusan pembatasan modal asing dalam perdagangan jasa, sedangkan PTA sendiri lebih kompleks kegiatannya yang meliputi pembentukan aturan investasi, Hak kekayaan intelektual, serta aturan kebijaksanaa persaingan.
} 
kapasitas, serta fasilitasi perdagangan. Jika ditelisik lebih mendalam, model EPA sendiri tidak terlalu berbeda dengan FTA, meskipun memasukkan aturan kesepakatan yang seimbang, realitas pelaksanaan belum dipastikan berjalan integratif, efisien dan seimbang.

Michael Blaker dalam bukunya Japanese International: Negotiating Style memaparkan empat gaya diplomasi yang kerap dilakukan Jepang dalam agenda ekonomi. Dua diantaranya sangat mencolok dalam orientasi dan aktulisasi EPA yaitu Happo bijinshugi (looking pretty for everyone) dan Enryo Gaiko (Restrained Diplomacy) (Blaker, 1977: 4-8). Gaya pertama yaitu upaya yang terlihat baik atau indah untuk semua orang, artinya Jepang sangat mempertimbangkan apa yang menjadi opini publik, terlihat bagaimana gerakan resistensi pada tahun 1970-an dimana Jepang disebut sebagai "animal economic" maka negera ini melakukan perbaikan signifikan baik dalam kerangka enonomi domestik, maupun diplomasi ekonomi. Gaya kedua merupakan kecendrungan Jepang untuk selalu mengendalikan setiap kebijakan dalam pemerintahannya sehingga cenderung otoriter.

Dalam melakukan kompetisi perdagangan Indonesia dan Jepang, kedua negara tersebut memiliki postur interdependensi. Jepang merupakan negara yang lebih unggul dari sektor ekonomi dengan ditunjang oleh kemajuan industrinya, namun terbatas dalam hal sumber daya alam (SDA). Sebaliknya, Indonesia sebagai negara berkembang masih dalam tahap pembelajaran, namun memiliki SDA melimpah yang tidak dimiliki oleh Jepang. Hingga saat ini, Jepang memiliki ketergantungan energi terhadap Indonesia. Realitas di atas sedikit menggambarkan pola interdependensi sejatinya memposisikan Jepang mendapat keuntungan yang relatif lebih tinggi dari Indonesia.

Segala keterbatasan dan ketergantungan yang dimiliki oleh kedua negara menjadi landasan terbentuknya kerjasama bilateral IJEPA. Kehadiran IJEPA merupakan turunan dari model EPA. Pelaksanaan kerjasama IJEPA pada dasarnya tidak terlepas dari tiga pilar utama sebagai landasan dalam kerjasama ini. Ketiga pilar tersebut antara lain; liberalization (pembukaan akses pasar), facilitation (pasar yang dipermudah) dengan adanya kepastian hukum, dan cooperation (kerjasama dan peningkatan khususnya bagi Indonesia) agar memiliki kemampuan bersaing.

Selain ketiga pilar tersebut, IJEPA juga mencakup sebanyak 13 sektor industi yang menjadi fokus untuk menunjang investasi Jepang di Indonesia, yaitu: pengerjaan logam, pencetakan alat mesin, promosi ekspor dan investasi, usaha kecil dan menengah, komponen otomotif, elektronik, baja, tekstil, petrokimia/oleokimia, logam non besi, serta makanan dan minuman (Atmawinata, Irianto, Diawati, \& Adlir, 2008). Dari kesemua sektor tersebut, yang menjadi perhatian penulis sesungguhnya ialah sektor otomotif. 
Pada dasarnya, sektor otomotif menjadi bagian dari sepuluh komoditas ekspor unggulan Indonesia. Dalam kurun waktu 15 tahun (20112015), tren ekspor otomotif jenis roda empat mencapai 153.87\% (Kementrian Perdagangan Republik Indonesia, 2016). Angka tersebut membicarakan dua ihwal sederhana, yaitu: (1) Sektor otomotif sebagai peringkat pertama dalam komoditas ekspor Indonesia. (2) Peningkatan ekspor Indonesia harus dibarengi dengan pemenuhan kemandirian teknologi.

Dalam skema kemitraan IJEPA, Indonesia menerapkan strategi yang untuk kepentingan nasional, antara lain (Atmawinata, Irianto, Diawati, \& Adlir, 2008: 2-3): 1) Sebagai sektor penggerak (driver activities) - Kedua negara telah menyepakati behwa sektor otomotif, elektrikal dan elektronik, dan alat berat merupakan sektor penggerak utama dalam mendorong pertumbuhan ekonomi masing-masing negara; 2) Program kesejahteraan (prosperity program) - ditujukan pada peningkatan daya beli masyarakat Indonesia melalui pembukaan akses pasar Jepang yang lebih luas bagi produk-produk unggulan Indonesia, peningkatan ekspor ke manca negara, peningkatan kapasitas daya saing industi manufaktur, dan harapan Indonesia untuk menjadi production base, menghasilkan produk manufaktur yang memiliki nilai tambah sehingga bisa diekspor dengan harga kompetitif; dan 3) Menjadi pusat pengembangan industi manufaktur - diharapkan industri manufaktur sebagai motor pembangunan kapasitas industri guna peningkatan daya saing.

Dalam strategi ketiga, Indonesia memproyeksikan terjadi transfer teknologi yang akan dikembangkan secara berlanjut. Kepentingan ini dikenal sebagai MIDEC. Dalam telaah diplomasi ekonomi Indonesia ke Jepang, jelas Indonesia telah melakukan upaya untuk mengamankan kepentingan nasional dalam lingkup domestik dan merespon dalam isuisu perdagangan. Hal ini dilakukan untuk memperkuat daya saing serta mencapai pertumbuhan ekonomi yang stabil dimana kontekstualisasi ekonomi-politik acapkali mengalami perubahan secara cepat. Jika mengikuti model kepentingan Indonesia dalam tujuan MIDEC, maka Indonesia memiliki tujuan strategis yang harus digapai, empat diantaranya terkait sektor otomotif (Atmawinata, Irianto, Diawati, \& Adlir, 2008: 47): 1) Meningkatnya daya saing industri manufaktur Indonesia; 2) Indonesia menjadi basis produksi produk manufaktur; 3) Meningkatnya pemakaian produk manufaktur berdaya saing tinggi "made in Indonesia" di pasar dunia; 4) Meningkatnya kemampuan sumber daya manusia industri melalui pelatian industri; 5) Meningkatnya daya beli masyarakat Indonesia melalui reprosperity development progam; 6) Berperannya Indonesia menjadi mitra strategis Jepang di pasar internasional khusnya di pasar ASEAN; dan 7) Terjalinnya kerjasama jangka panjang Indonesia dan Jepang dalam pengembangan industri manufaktur dengan Jepang di bawah payung 


\section{MIDEC-IJEPA.}

Harapan Indonesia melalui skema kemitraan ini dianggap tinggi dan optimistik. Sebelum penandatangan IJEPA, Indonesia telah menikmati surplus perdagangan dengan Jepang dalam kurun waktu sepuluh tahun (sebelum tahun 2008) terakhir meningkat Jepang utama ekspor Indonesua dengan share 21\% di tahun 2007 yang melebihi AS dan China. Hal ini ditunjukkan dengan tren neraca perdagangan Indonesia dengan Jepang sejak tahun 2000 sampai 2007 yang cenderung naik dan mencapai US\$17.1 miliar pada tahun 2007 (Dachlan, 2015: 7).

Sehubungan dengan penguatan ini, Indonesia berambisi menggapai peluang yang lebih besar. Kepentingan ini diturunkan dalam penyepakatan IJEPA, dengan skema penurunan bea masuk dengan tarif preferensi umum dan tarif USDFS (User Specific Duty Free). ${ }^{3}$ USDFS kemudian menjadi permintaan utama Jepang untuk memudahkan langkah Jepang agar bisa masuk ke pasar Indonesia, sebagai bargaining maka Jepang memberikan Indonesia program pengembangan industri melalui skema MIDEC yang salah satunya sektor otomotif. Jepang bersedia menurunkan sekitar 80\% pos tarifnya agar tarif bea masuk diturunkan menjadi $0 \%$ saat IJEPA berlangsung. Sementara itu, Indonesia menurunkan hanya sekitar 35\% dari pos tarifnya.

Dalam perjalanannnya, janji dari kerjasama IJEPA melalui MIDEC tidak memperlihatkan bentuk nyata. Realitasnya, terdapat beberapa pelaksanaan yang tidak sesuai dengan harapan atau ekspektasi dari diplomasi awal. Pertama, harapan adanya peningkatan nilai ekspor Indonesia ke Jepang sebesar 20\% dianggap gagal. Dalam kurun tiga tahun setelah kesepakatan, produk non-migas Indonesia ke Jepang hanya $8.89 \%$. sebaliknya, impor non-migas Indonesia dengan Jepang tumbuh 26.6\% di tahun yang sama (Dachlan, 2015: 8). Artinya, dalam sektor pemajuan produksi ekspor otomotif ke Jepang dianggap rendah, yang terjadi produk otomotif Jepang makin berkelindaan.

Kedua, impian MIDEC tidak memiliki standar ukuran. Pada dasarnya MIDEC sebagai kompensasi bagi industri domestik Indonesia seharusnya mampu memberikan peranan dalam mendorong kegiatan industri domestik Indonesia. Ironisnya, Jepang sama sekali tidak memperlihatkan keseriusan dalam melakukan transfer teknologi khususnya sektor otomotif. Realitas ini menggambarkan, bahwa diplomasi Indonesia dibuat kalah dalam proses implementasi kebijakan. Posisi Jepang yang dianggap tidak patuh,

${ }^{3}$ USDFS merupakan fasilitas penetapan bebas tarif bea masuk atas impor bahan baku dari Jepang yang digunakan dalam kegiatan produksi oleh industri-industri tertentu yang berbasis baja. Hal ini termasuk dalam sektor otomotif, sebab hampir kesemua material hard mobil menggunakan bahan ini. 
boleh jadi mempraktikkan gaya diplomasi ekonomi "Kiken kaiki" - yaitu diplomasi menghindari resiko akibat pertimbangan sepihak dalam menilai dampak dan keuntungannya bagi Jepang (Blaker, 1977).

Penulis menilai tawaran ambisius dari IJEPA sejatinya telah dipertimbangkan matang-matang oleh Jepang, sebab akan sulit bagi Indonesia melakukan ekspor tinggi sedangkan belum memiliki kemandirian utuh. Asumsi penulis sebenarnya dipengaruhi oleh penelitian Sigit Setiawan. Penelitian ini menilai dampak dari IJEPA terhadap kontribusi nilai ekspor Indonesia ke Jepang dalam tahun 2011 tidak terlalu signifikan (Setiawan, 2012). Sigit memperlihatkan sebuah rekayasa, bahwa ada atau tidak adanya IJEPA tidak mempengaruhi peningkatan berlebih dari produk ekspor Indonesia ke Jepang. Selisih nilai antara diterapkannya IJEPA atau tanpa IJEPA hanya sebesar US\$2.727.360.000:

Tabel 1. Rekayasa Nilai Perdagangan IJEPA

\begin{tabular}{|c|c|c|c|}
\hline \multicolumn{2}{|l|}{ Periode } & \multirow{2}{*}{$\begin{array}{l}\text { Total Nilai } \\
\text { Ekspor } \\
\text { US\$26.082.260.000 }\end{array}$} & \\
\hline Pra IJEPA & $\begin{array}{l}\text { Juli } 2007 \text { - } \\
\text { Juni } 2008\end{array}$ & & \\
\hline \multirow[t]{2}{*}{$\begin{array}{l}\text { Pasca } \\
\text { IJEPA } \\
\text { berlaku }\end{array}$} & & $\begin{array}{l}\text { Kondisi aktual } \\
\text { (dengan skema } \\
\text { IJEPA) }\end{array}$ & $\begin{array}{l}\text { Hasil estimasi } \\
\text { simulasi tanpa } \\
\text { skema IJEPA }\end{array}$ \\
\hline & $\begin{array}{l}\text { Juli } 2010 \text { - } \\
\text { Juni } 2011\end{array}$ & US\$33.807.290.000 & US\$30.807.930.000 \\
\hline
\end{tabular}

Selanjutnya, dari program MIDEC menjadi optimisme sesaat semata, kalaupun terjadi transfer teknologi, bukan berarti perpindahan mutu teknologi tinggi. Jepang akan berhati-hati melakukan transfer teknologi dengan mutu tinggi, melihat Indonesia merupakan negara emerging market, serta memiliki tenaga terampil yang murah yang akan menjadi ancaman Jepang di hari esok. Hal inilah penulis anggap sebagai mekanisme politik Jepang yang cenderung proteksionis, meskipun telah melangsungkan kerjasama IJEPA.

Kegalalan atas capaian IJEPA sendiri, bagi penulis adalah problema diplomasi ekonomi Indonesia selama ini. Penulis tidak sepihak mempersoalkan Jepang yang memperlihatkan sikap tidak patuh. Pada dasarnya arena diplomasi ekonomi sangat syarat dengan agenda politis. Artinya kata kunci diplomasi ekonomi menyangkut kekuatan ekonomi 
ralatif, rezim, kepentingan, dan kebijakan domestik (Woolcock, 2013: 18). Persoalan yang dihadapi oleh negara berkembang, seperti Indonesia ialah problem diplomasi ekonomi yang rapuh turut mempengaruhi implementasi kebijakan.

Kishan Rana membagi tipologi diplomasi ekonomi menjadi empat jenis yaitu: traditional, niche-focused, evolving, dan innovative (Rana, 2007). Sebagai rujukan tersebut, penulis memandang Indonesia sebenarnya mengalami dua persoalan besar, yakni pengelolaan kebijakan (policy management) dan manejemen ekonomi eksternal (external economic management). Dua aspek ini memperlihatkan Indonesia masih terbatas dalam memainkan peranan Kementrian Luar Negeri (Kemenlu). Dalam realitas kepemimpinan Susilo Bambang Yudhoyono, optimisme IJEPA sekedar luapan kepentingan Kementrian Koordinator Bidang Perekonomian (Menko Perekonomian). Postur Menko Perekonomian mencatat 19 kementrian terkait, tetapi tidak memasukkan Kemenlu.

Ini dipandang sebagai persoalan penting, padahal peranan Kemenlu tidak terbatas hanya penghubung semata. Sebaliknya, Kemenlu memiliki peranan ekstra dimana dapat memformulasikan dan mengimplementasikan kebijakan ekonomi, baik yang bersifat eksternal dan internal di Indonesia. Sementara itu, pemerintahan di bawah SBY justru mengandalkan beberapa Kementrian dalam aktivitas eksternal semisal Kementrian Perdagangan untuk aktifitas perdagangan internasional dan Badan Kordinasi Penanaman Modal (BKPM) untuk aktifitas moneter dan finansial.

Artinya, SBY telah menghilangkan peran Kemenlu sebagai salah satu aktor sentral diplomasi ekonomi. Kondisi ini memperlihatkan struktur dan fungsi aktor mempengaruhi diplomasi ekonomi beserta implementasinya. Meminjam tipologi Rana, Indonesia dapat dikategorikan sebagai praktik diplomasi ekonomi - "niche focused". Dalam perbandingan negara maju dengan praktik evolving dan innovative, telah menggabungkan antara fungsi dari MoFA (Ministry of Foreign Affairs) dan instansi yang mengatur aktivitas ekonomi eks-ternal. Sebagai contoh, Australia memiliki DFAT (Australian Department of Foreign Affairs and Trade) yang menggabungkan antara fungsi departemen perdagangan, departemen luar negeri dan instansi yang membidangi bantuan pembangunan (development assistance) (Killian, 2012: 176).

Persoalan diatas telah menggambarkan bahwa posisi Indonesia sendiri mengalami kerugian oleh akibat kemitraan yang dijalin melalui IJEPA. Selanjutnya, postur diplomasi ekonomi Indonesia sendiri mengalami persoalan internalisasi. Dari kedua persoalan tersebut, Indonesia memiliki batu sandungan yang akan mempengaruhi skema kebijakan selanjutnya. Sebelum implikasi kerugian begitu memanjang, Indonesia harus berbenah dan mengevaluasi program kerjasama yang tengah terbangun. Sedangkan, 
Alat bargaining dalam evaluasi kebijakan IJEPA yaitu - Indonesia dan Jepang memiliki bangunan kemitraan yang sangat lama, sehingga menjadi modalitas Indonesia berhadapan dengan Jepang. Perlu diketahui, meskipun Jepang bersikap proteksionis pada dasarnya Jepang berhati-hati menjaga kemitraan yang telah terbangun. Jika mengingat tragedi sebelumnya, Jepang pernah mengalami kritik tajam dari berbagai negara Asia Tenggara, salah satunya Indonesia. Maka Jepang tetap hirau dengan gaya diplomasi "Happo Bijnshugi" yaitu upaya berperilaku adil dan mempertimbangkan opini publik.

\section{Relasi Dagang Toyota ke Indonesia}

Kerjasama Jepang dengan Indonesia bisa dikatakan menemui babak baru saat kerjasama ini dilakukan dengan menggandeng korporasi otomotif bernama Toyota. Dalam ritus diplomasi ekonomi transnasional, pelaksanaan kemitraan korporasi sangat membutuhkan dukungan kuat dari home country ke host country. Kerjasama ini diawali dengan disepakatinya Toyota untuk menanamkan modalnya di Indonesia dengan PT. Astra International Corporation sebagai distributor tunggalnya tahun 1970an. Kebijakan pemerintahan Orde Baru mengeluarkan aturan yang berketetapan hukum yaitu SK Menteri Perindustrian No.168/M/SK/9/79 (medeka, 2013).

Hubungan kerjasama (partnership) Toyota dengan perusahaan domestik Indonesia dimulai dengan model join venture. Dengan awal perbandingan kepemilikan saham sebanyak 51\% dipegang oleh PT. Toyota Astra Motor (TAM) dan 49\% Toyota Motor Corporation (TMC) asal korporasi Jepang. kepemilikan saham ini kemudian bertransformasi seiring keberhasilan Toyota di Indonesia yang menjadi 95\% saham dipegang oleh TMC dan 5\% lagi dipegang oleh PT. TAM khususnya dalam manufacturing. Kemudian dari marger kedua perusahaan ini terbentuklah TMMIN (Toyota Motor Manufacturing Indonesia) yang berpusat di Jakarta. Artinya PT. TMMIN (produsen) merupakan anak perusahaan TMC yang juga produsen mobil terbesar dunia yang berkedudukan di Jepang. Selain itu, TMC turut menguasai saham PT.TAM (distributor) sebesar 40\% dan PT. Astra International sebesar 60\% (Toyota Motor Manufacturing Indonesia, 2015).

PT. TMMIN mempunyai tiga kawasan produksi, yaitu Sunter 1, Sunter 2 dan Karawang. Sunter 1 difokuskan pada produksi seluruh mesin mobil, seperti mesin mobil Avanza, Kijang Innova, dan Rush, sedangkan Sunter 2 lebih difokuskan untuk proses stamping, casting, packing dan vanning, dan proses penyatuan seluruh komponen mobil (Assembly) dilakukan di Karawang. Sejak didirikan tahun 1971, PT. TMMIN terus meningkatkan inovasi dan kinerja perusahaan. Berikut adalah perjalanan 
panjang dan kejadian penting yang terjadi pada perusahaan PT. TMMIN. Untuk mengetahui keberlangsungan relasi korporasi Toyota ke Indonesia dengan pelibatan perusahaan domestik, berikut adalah perjalanan panjang yang terjadi pada PT. TMMIN:

\section{Tabel 2. Perkembangan Perusahaan}

\begin{tabular}{|l|l|}
\hline Tahun & Perkembangan Perusahaan \\
\hline 1971 & $\begin{array}{l}\text { Peresmian PT. TAM (Toyota-Astra Motor) sebagai importer dan distributor } \\
\text { kendaraan Toyota di Indonesia }\end{array}$ \\
\hline 1973 & Didirikan pabrik perakitan PT. Multi Astra \\
\hline 1976 & Didirikan PT. Toyota Mobilindo sebagai pabrik komponen \\
\hline 1977 & Kijang pertama kali diluncurkan ke publik \\
\hline 1982 & Pabrik mesin PT. Toyota Engine Indonesia mulai beroperasi \\
\hline 1987 & Ekspor perdana kijang ke beberapa negara Asia Pasifik \\
\hline 1989 & $\begin{array}{l}\text { Merger empat perusahaan Toyota di Indonesia: PT. Toyota Astra Motor, PT. } \\
\text { Multi Astra, PT. Toyota Mobilindo dan PT. Toyota Engine Indonesia }\end{array}$ \\
\hline 1996 & Peluncuran unit produksi Toyota ke 1.000.000 \\
\hline 2000 & Pabrik moderen Karawang diresmikan \\
\hline 2003 & $\begin{array}{l}\text { PT. TAM berubah nama menjadi PT. TMMIN (Toyota Motor Manufacturing } \\
\text { Indonesia) dan didirikan PT. TAM sebagai distributor }\end{array}$ \\
\hline 2004 & $\begin{array}{l}\text { Peluncuran Toyota Avanza sebagai kendaraan kolaborasi PT. TAM, PT. } \\
\text { TMMIN dan PT. Astra Daihatsu Motor. Peluncuran Toyota Kijang generasi } \\
\text { V dan Kijang Innova }\end{array}$ \\
\hline
\end{tabular}

Pola kerjasama di atas telah ditandai bahwa Indonesia - Jepang telah membangun kemitraan yang semakin kompleks melalui peranan korporasi otomotif. Bahkan kerjasama ini dikuatkan kembali melalui skema kerjasama IJEPA. Di tengah menguatnya program kemitraan, yang patut dikritisi ialah pengaruh Toyota melalui IJEPA bagi Industri otomotif dalam negeri. Penulis melihatnya dalam dua implikasi seimbang yaitu positif dan negatif.

Implikasi positif yang amat sederhana berupa medium pembelajaran bagi industri dalam negeri dengan menghasilkan produksi yang berkualitas tinggi. Meskipun masih memperlihatkan perbedaan yang amat jauh antara Indonesia dan Jepang, setidaknya Indonesia bisa mengambil kesempatan proses perpindahan teknologi. Toyota sangat hirau kepada orientasi pasar yang menjadi tolok ukur bagi industri otomotif dalam negeri untuk terus berkembang. Konsentrasi Toyota tersebut diharapkan adanya pelaksanaan kebijakan yang konsisten. Dalam skema IJEPA, Indonesia sebagai host country dari Toyota - maka memiliki hak untuk mengatur dan menentukan langkah-langkah yang merupakan agenda kepentingan nasional. Di tengah konsentrasi Toyota menjadikan orientasi pasar di Indonesia, maka konsekuensi logisnya ialah Toyota perlu melakukan pemenuhan kualitas 
produksi yang berdaya saing (ekspor) di regional Asia Tenggara, maupun negara lain.

Implikasi negatif yaitu skema kemitraan yang dibangun bisa menjadi keuntungan sepihak dari korporasi Toyota. Pada dasarnya skema klausal IJEPA memuat suatu ancaman bagi Indonesia. Posisi ini terlihat dalam penurunan tariff bea masuk hingga $0 \%$, dengan target peningkatan nilai ekspor Indonesia ke Jepang. Celakanya, nilai ekspor ke Jepang sangat sulit menembus dari perkiraan awal, sebab produk Indonesia memiliki daya saing yang lemah dan Jepang masih cenderung bersikap proteksi. Persoalan kedua, ialah skema IJEPA yang memberi janji berupa transfer teknologi (MIDEC) pada kenyataanya sulit digapai, sebab impor otomotif Jepang terus meningkat, sedangkan ekspor Indonesia sangat rendah. Dalam level domestik, Indonesia justru terkesan memanjakan importir, sedangkan peningkatan mutu produksi yang menyangkut komponen lokal Indonesia belum mencapai 100\% dengan produk tertentu seperti Kijang, Avanza, Rush, dll. Di tengah penguasaan pasar otomotif Toyota di Indonesia, dalam distributornya-pun belum memperlihatkan kemandirian pengusaha lokal. Korporasi Toyota (TMC) menguasai saham PT.TAM sebagai distributor sebesar 40\%, skema ini turut berkorelasi dalam kalkulasi keuntungan penjualan di Indonesia, terlebih Indonesia sebagai negara populasi tertinggi dalam pembelian mobil. Pada akhirnya realitas IJEPA, melahirkan sebuah skema domestik - pemerintah Indonesia hanya menjadi pedagang mobil di negeri sendiri, bukan menjadi negara dengan kualitas indsutri yang signifikan.

Untuk menambah perdebatan dalam tulisan ini, penulis memaparkan perbandingan produksi Indonesia dengan berbagai negara di kawasan Asia Tenggara. Tujuannya yaitu membandingkan peforma industri otomotif domestik - yang berpengaruh dalam arena pasar bebas. Dalam kurun waktu 20 tahun (1990-2010), peforma nilai perdagangan otomotif di ASEAN mengalami peningkatan. Tiga negara, diantaranya Indonesia, Thailand, dan Malaysia menunjukkan perolehan nilai ekspor dan impor yang berbeda di sektor otomotif. Dalam tahun 2010, peforma nilai ekspor Indonesia tidak jauh berbeda dengan Malaysia. Thailand merupakan negara yang paling berhasil di ASEAN yang mampu membangkitkan nilai ekspornya, dengan kalkulasi delapan kali lipat dari nilai ekspor Indonesia. Kondisi ini memperlihatkan bahwa dalam persaingan industri otomotif sendiri, Indonesia kalah telak dibanding Thailand. Berikut ini memperlihatkan Value dari manufaktur dan ekspor-impor otomotif di tiga negara (Tai, 2016: 36): 
Tabel 3. Nilai Perdagangan Otomotif ASEAN

\begin{tabular}{|l|l|l|l|l|l|l|l|l|l|}
\hline \multicolumn{1}{|c|}{ Trade growth rate (\%) } & \multicolumn{1}{l|}{ Trade Value } \\
\hline & & 1990 & 1995 & 2000 & 2010 & $\begin{array}{l}1990- \\
2000\end{array}$ & $\begin{array}{l}2000- \\
2010\end{array}$ & $\begin{array}{l}1990- \\
1995\end{array}$ & $\begin{array}{l}1995- \\
2010\end{array}$ \\
\hline \multirow{3}{*}{ Indonesia } & Ekspor & 0.02 & 0.13 & 0.37 & 2.55 & 175 & 58.9 & 110 & 124.1 \\
\cline { 2 - 10 } & Impor & 1.52 & 3.14 & 1.87 & 5.56 & 2.3 & 45.6 & 21.3 & 5.1 \\
\hline \multirow{3}{*}{ Thailand } & Ekspor & 0.11 & 0.49 & 2.42 & 18.7 & 201 & 67.3 & 69.1 & 247.8 \\
\cline { 2 - 10 } & Impor & 2.65 & 5.18 & 2.08 & 8.54 & -2.2 & 31.1 & 19.1 & 4.3 \\
\hline Malaysia & Ekspor & 0.12 & 0.28 & 0.31 & 1.33 & 15.8 & 32.9 & 26.7 & 25 \\
\cline { 2 - 10 } & Impor & 1.31 & 2.79 & 1.83 & 5.76 & 4 & 21.5 & 22.6 & 7.1 \\
\hline
\end{tabular}

Sementara itu, meskipun Malaysia berada diposisi terakhir dalam tiga negara tersebut, setidaknya Malaysia memiliki produk otomotif nasional bernama Proton (Prototype Nasional). Bahkan, produk ini turut mengusik persaingan pasar di Indonesia. Berikut ini data yang dihimpun oleh GAIKINDO mengenai total unit produksi yang terjual di pasar Indonesia:

Tabel 4. Produksi Mobil Malaysia

\begin{tabular}{|l|l|l|l|l|l|l|l|}
\hline Malaysia & 2010 & 2011 & 2012 & 2013 & 2014 & 2015 & 2016 \\
\hline Proton & 2.126 & 1.926 & 2.263 & 1.088 & 523 & 220 & 589 \\
\hline
\end{tabular}

Data diatas menunjukkan tren penjualan Proton di Indonesia dari tahun 2010 ke 2016, mengalami penurunan. Meskipun demikian, penurunan diatas memastikan satu hal penting - Malaysia lebih unggul dalam hal kemandirian otomotif, dibanding Thailand dan Indonesia. Penelitian Wan-Ping Tai dan Samuel C. Y. Ku menyebut dua negara di ASEAN seperti Thailand dan Malaysia memiliki keunggulan komparatif masing-masing dalam sektor otomotif. Kedua penulis ini menemukan suatu model pendekatan terhadap industri otomotif. Temuannya yaitu Malaysia cenderung menggunakan pendekatan pembangunan independen, sedangkan Thailand menggunakan pembangunan dependensi.

Dua pendekatan ini sama-sama memiliki keuntungan dan kerugian. (1) Independen memiliki keuntungan yaitu adanya proteksi untuk produksi massal, sedagkan kerugiannya ialah beban finansialnya diterima oleh Negara. (2) Dependensi memiliki beban finansial yang harus diterima oleh pemerintah bernilai sedikit, sedangkan kerugiannya mencakup - industri otomotif didominasi oleh aliran modal luar (Abdullah, 2006). Dari dua model ini, pada dasarnya peranan kuat dari pemerintah sangat menjamin berlangsungnya kemandirian teknologi. 
Praktik Malaysia tentu sebagai orientasi developmental-state (Tai \& Ku, 2013: 7677). Meskipun, Thailand saat ini memiliki nilai ekspor otomotif tertinggi, namun keuntungan yang lebih akan tetap diterima ke pemilik saham yang tertinggi. Saham ini tentunya berasal dari korporasi otomotif Jepang seperti Toyota (TMC).

Keberlangsungan Jepang dalam korporasi otomotif di ASEAN telah menjadi pemain kunci. Bahkan, dalam membuat produknya tetap meraih kesusksesan di Asia Tenggara, tidak jarang Jepang mengajak negara mitranya membangun sebuah negosiasi baru, dan selalu menjanjikan investasi baru. Pada dasarnya industri otomotif sangat membutuhkan investasi dan teknologi yang tinggi. Korporasi Jepang mempunyai strategi untuk mengintegrasikan basis produksi dan pembagian wilayah tenaga kerja. Toyota akan mempertahankan pasarnya melalui liberalisasi pasar serta mereka mempunyai cara untuk berintegrasi dengan pemerintah seperti Indonesia agar tujuan dan kepentingan mereka tercapai (Yoshimatsu, 1999: 496).

\section{Derajat Ketergantungan ke Toyota}

Untuk melihat apakah Indonesia mampu berhasil mendapatkan keuntungan dari kerjasama dengan Toyota melalui IJEPA, maka perlu untuk mengukur tingkat ketergantungan Indonesia ke Toyota (Jepang). Alasannya ialah kondisi ketergantungan yang rendah maupun tinggi berimplikasi positif kepada penggapaian kepentingan Indonesia, yang kemudian menjadi nilai tawar diplomasi selanjutnya.

Jie Huang dan Kazimiers M. Slomczynski menawarkan berbagai dimensi dan ukuran dalam melihat tren ketergantungan ekonomi suatu negara. Rumusan ukurannya ada pada derajat dependensi cross country dengan tiga indikator utama yaitu; perdagangan, hutang, dan investasi luar negeri (Huang \& Słomczyński, 2003). Tulisan ini menggunakan dua indikator, yaitu: nilai perdagangan (ekspor dan impor) dan investasi luar negeri. Selanjutnya, dalam menelusuri ketergantungan yang dialami oleh Indonesia kepada aktor (Jepang) dan agen (Toyota), maka dua indikator tadi dipecah menjadi lima variabel ukuran yaitu: persentase impor otomotif ke Indonesia - Jepang dari total impor otomotif Indonesia keseluruhan, persentase FDI Jepang di Indonesia dari total FDI Indonesia, nilai impor otomotif di Indonesia, market share Toyota di Indonesia, dan penjualan Toyota di Indonesia. Pertama yaitu tren impor otomotif Indonesia - Jepang. Dari grafik di bawah ini menunjukkan nilai impor Indonesia mengalami posisi fluktuatif, tahun 2009 menurun drastis dari angka $40 \%$ menuju $28 \%$. Artinya penurunan ini mencapai hingga 12\%. Jika menguji penurunan tren tersebut, disebabkan oleh implikasi krisis finansial AS yang menganggu konstelasi perdagangan global. Kehadiran IJEPA pada tahun 2008 turut mempengaruhi peningkatan, kemudian tahun 2014 ke 2015 mengalami lonjakan tajam sebesar $20 \%$. 


\section{Grafik 1. Presentasi Impor Otomotif Indonesia - Jepang dari Total Impor Otomotif Indonesia Keseluruhan}

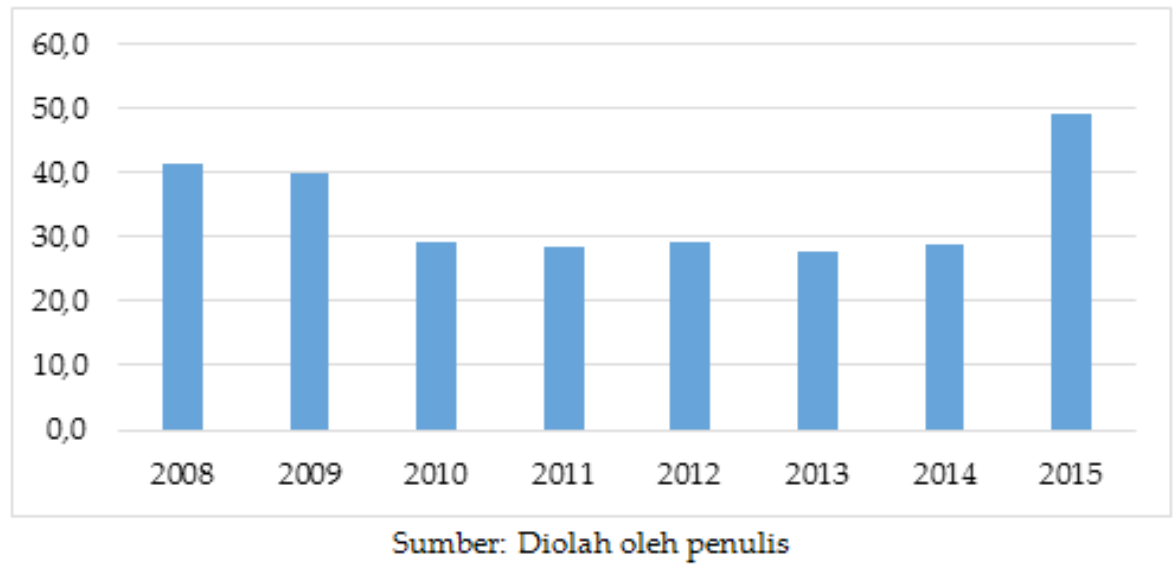

Kedua yaitu menyangkut nilai investasi langsung. Grafik dibawah memperlihatkan Indonesia menerima investasi yang sangat besar dari Jepang. Tahun 2012 merupakan investasi tertinggi yang mencapai $41.6 \%$, sedangkan ditahuntahun lainnya, nilai investasi hampir seimbang dengan rata-rata nilai investasi $29 \%$.

\section{Grafik 2. Persentase FDI Jepang di Indonesia dari Total FDI Indonesia}

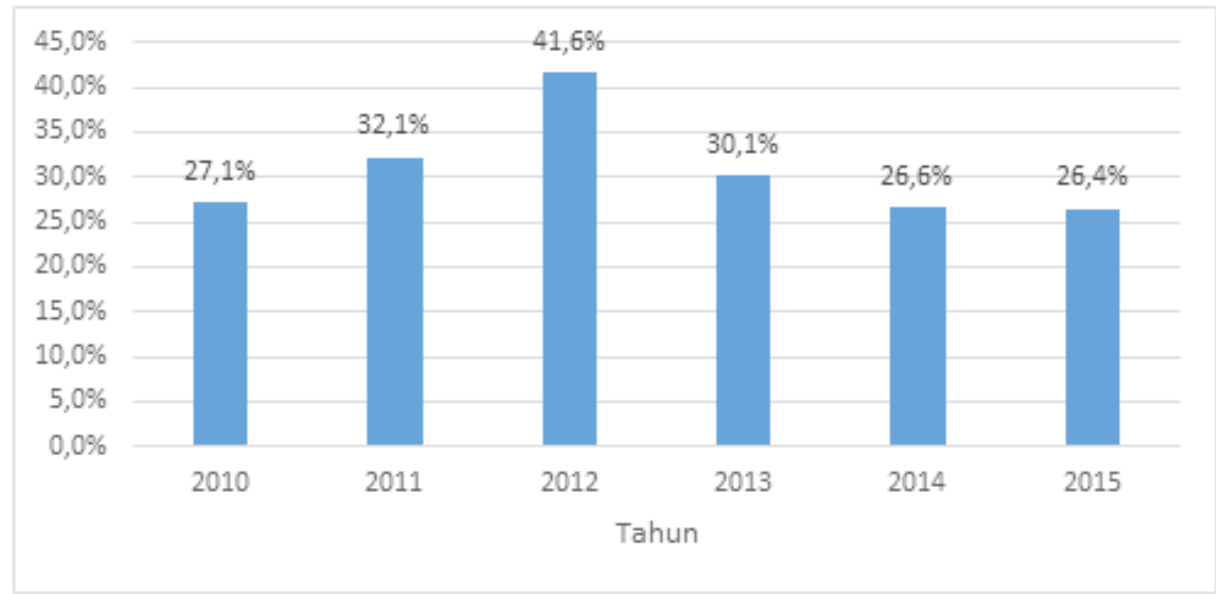

Sumber: Diolah oleh penulis

Sementara itu, FDI Jepang di Indonesia dengan perbandingan FDI total dengan FDI Jepang memperlihatkan posisi Indonesia mendapat bantuan modal yang amat tinggi. Tren diatas menunjukkan presentase fluktuatif, tahun 2012 merupakan nilai investasi yang amat tinggi dan tahun 2015 diikuti dengan presentase yang sangat rendah dalam kurun waktu lima tahun. Meskipun demikian, tingkat aliran 
modal Jepang ke Indonesia sangat tinggi dibanding negara-negara industri maju lainnya.

Thee Kian We memandang investasi Jepang ke Indonesia terletak pada beberapa sektor industri manufaktur, salah satunya otomotif. Banyaknya investasi jeoang pada sektor manufaktur dikhawatirkan Jepang akan menginvansi perekonomian Indonesia (Wie, 2005). Perlu diketahui, Jepang sendiri telah melakukan perpindahan modal yang amat tinggi atau terkonsentaris di Asia Tenggara. Hidetaka Yoshimatsu menilai tingginya FDI ke Asia Tenggara, salah satunya ke Indonesia lambat laun memberi ketergantungan. Bahkan keuntungan yang diterima menggapai sebesar 90\% disetiap pasarnya di ASEAN (Yoshimatsu, 1999: 499).

\section{Grafik 3. FDI Jepang di Indonesia}

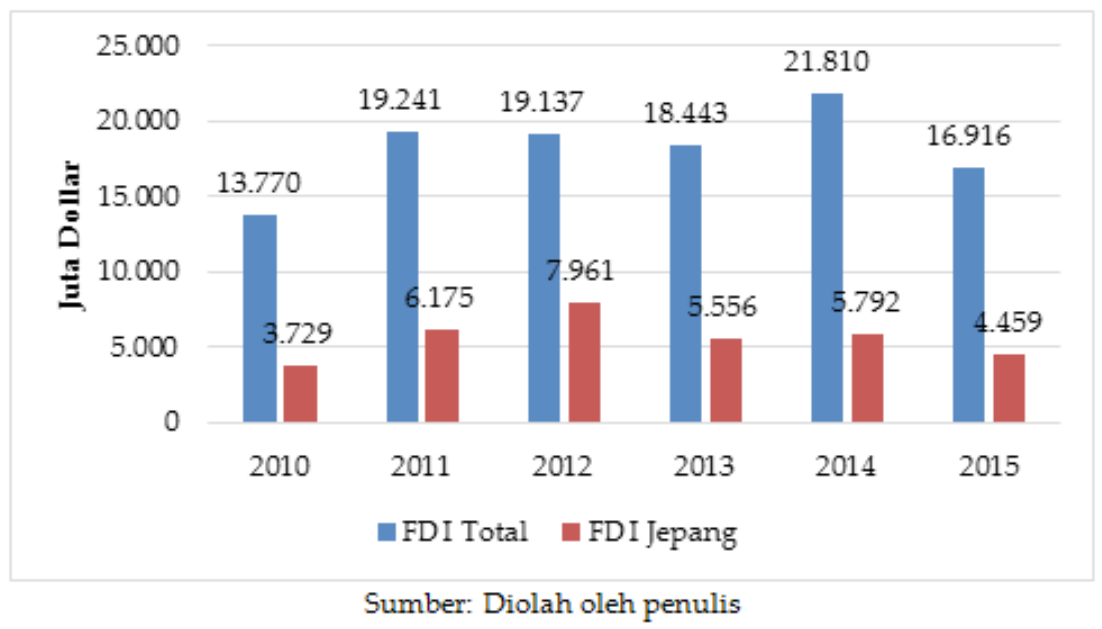

Ketiga yaitu nilai impor otomotif Indonesia dengan perbandingan dengan negara-negara lain. Grafik dibawah menunjukkan tren produk penjualan dari Jepang sangat tinggi dibanding negara produsen lain. Artinya angka yang fluktuatif ini menjadi penanda bahwa Indonesia sudah menjadi pangsa pasar utama bagi Jepang, khususnya kendaran murah. Meskipun data dibawah memperliatkan corak impor Thailand yang sangat tinggi, perlu diketahui bahwa produksi Thailand dalam industri otomotif berasal dari perusahan Jepang sendiri. Konteks ini memberi dua tren penting. Pertama, Thailand telah melakukan ekspansi dan dominasi produksi otomotif yang menjadikan Indonesia sebagai negara sasaran produk. Kedua, Thailand telah menjadi pengembang industri otomotif yang berkualitas tinggi di Asia Tenggara. Dua tren ini pada akhirnya mengabarkan bahwa Indonesia lambat laun hanya menjadi negara konsumen, bukan menjadi produsen. 


\section{Grafik 4. Nilai Impor Kendaraan Bermotor 1 Menurut Negara Asal Utama} (Nilai CIF: juta US\$)

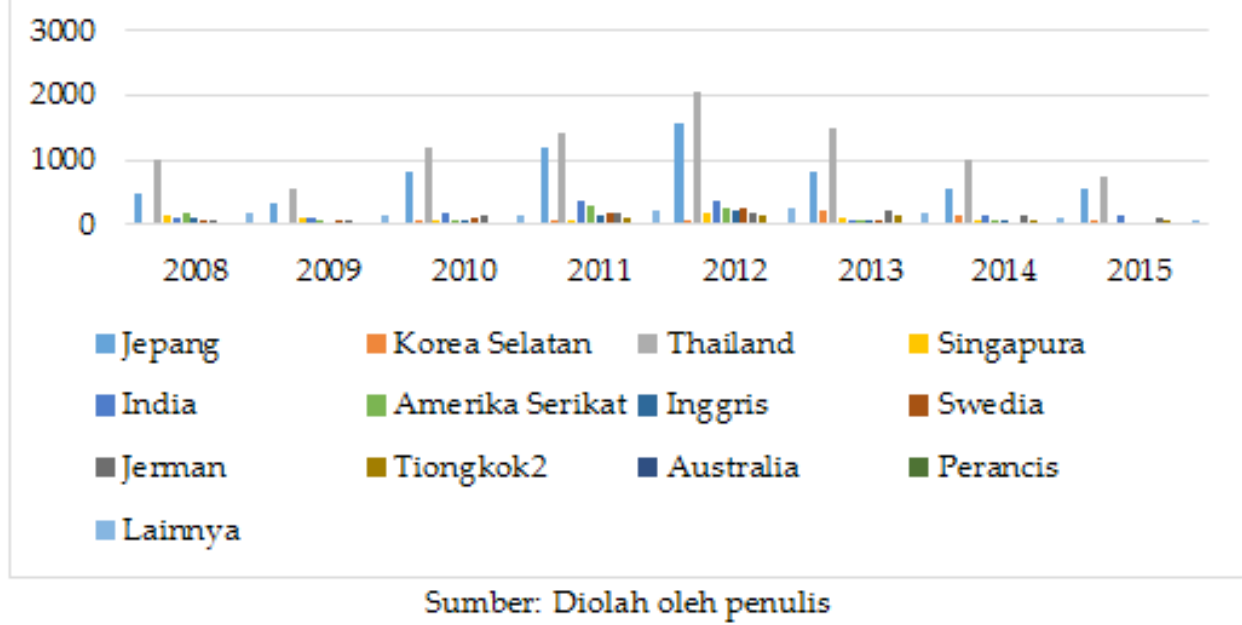

Kempat yaitu tren market share Toyota Indonesia. Dalam grafik di bawah menunjukkan bahwa posisi Toyota dengan produk lainnya (yang berasal dari Jepang) lebih diminati oleh kebanyakan masyarakat. Toyota menguasai market share hingga $36 \%$, dibanding Honda hanya sebesar 19\%. Derajat di bawah menggambarkan bahwa Toyota dipandang relevan menjadikan Indonesia sebagai negara utama dalam target pemasaran.

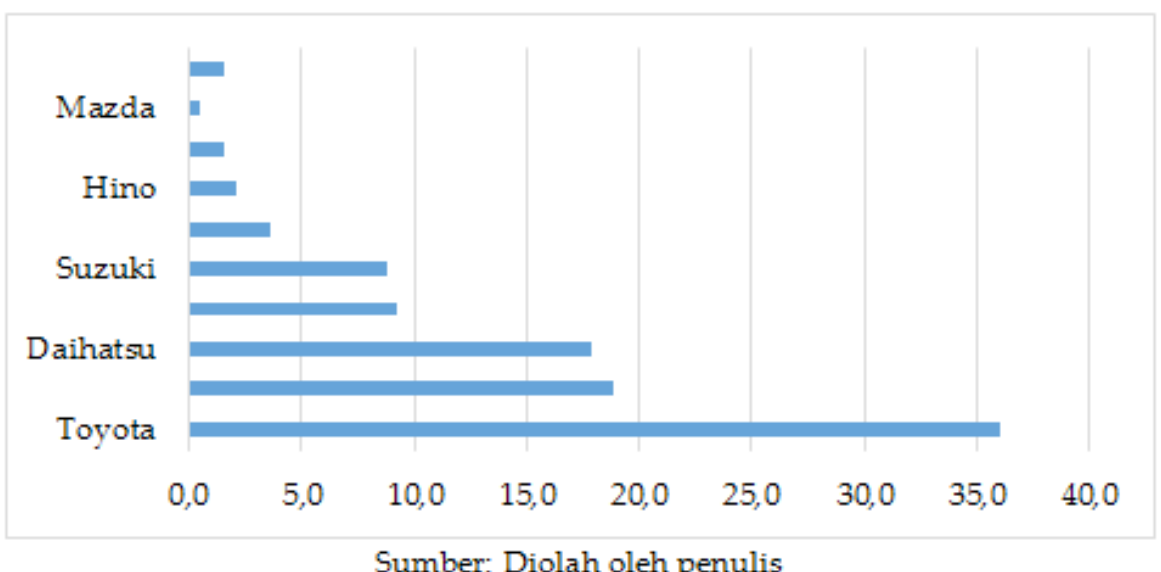


Terakhir ialah variabel nilai penjualan Toyota di Indonesia. Postur ini memperlihatkan nilai yang sangat tinggi dibanding dengan merek dagang lainnya. Dalam grafik di bawah, penjualan unit mobil Toyota mencapai di atas 350.000 Unit. Dalam urutan kedua, Honda hanya berhasil mendapat nilai penjualan sebesar 200.000 unit. Artinya market share yang tinggi berkonsekuensi logis dari meningkatnya penjualan, seperti yang dialami Toyota.

\section{Grafik 6. Penjualan Otomotif di Indonesia Tahun 2016}

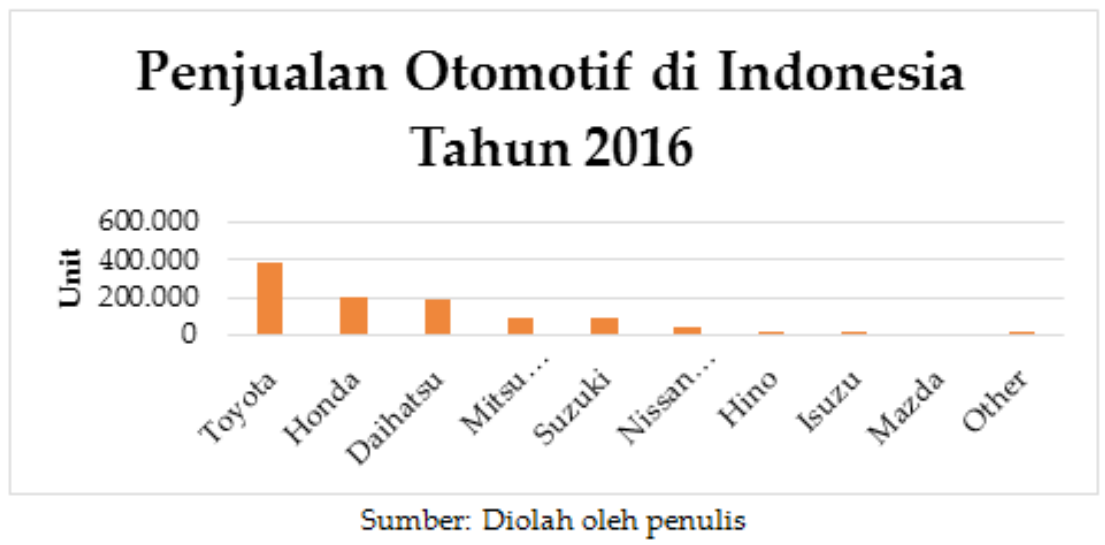

Dari kelima variabel diatas, terdapat suatu tren yang cukup menarik, yaitu Indonesia dijustifikasi sebagai negara yang amat bergantung kepada korporasi otomotif Toyota. Selanjunya, meningkatnya tren ketergantungan Indonesia kepada Toyota tentu menciptakan kemandirian teknologi yang semakin sulit untuk dijangkau. Di tengah pendalaman dependensi Indonesia kepada korporasi Toyota, sudah seharusnya Indonesia menguatkan peranan "negara" dalam momentum kemandirian dalam sektor otomotif.

Susan Strange yang dikenal sebagai neo-strukturalis, kerapkali menjatuhkan kritiknya kepada pasar. Pemikirannya berangkat dari konsep structural power saat mengkaji hubungan negara dan pasar pada era globalisasi. Dalam karyanya, "States and Markets", Strange melihat pola kekuasaan pada rezim neoliberal adalah kekuasaan yang tidak langsung, yakni kekuasaan yang didasarkan pada pembagian kerja antar institusi ekonomi internasional (Strange, 2004: 24-25). Meskipun, Strange membangun argumentasi kepada institusi hegemonik - penulis menilai ada kesusaian dengan perilaku Jepang ke Indonesia melalui dimensi norma yaitu aturan perdagangan IJEPA.

Kesamaan ini dirangkul oleh paham neoliberalisme melalui FTA. Jepang menggeser wacana neoliberalisme dari FTA yang seringkali merugikan negara berkembang menjadi EPA. EPA sendiri selalu dibayangkan oleh Jepang sebagai kerjasama yang akan menguntungkan dua belah pihak. Tetapi, dalam perdaganagan 
bebas tidak sekedar dilihat sebagai keuntungan yang absolut, melainkan relative gain. Dalam postur presentase di atas, Indonesia sama sekali tidak mendapat keuntungan lebih, sedangkan beban yang harus diterima ialah imaji kemandirian industri otomotif melalui MIDEC mengalami stagnansi. Lambat-laun, Indonesia terus mengalami kerugian mulai dari model diplomasi ekonomi yang salah, hingga implementasinya.

Dalam pendekatan ekonomi-politik internasional, paham liberalisme melihat perdagangan (interdependensi) sebagai upaya mendulang keuntungan bersama (Keohane \& Nye, 2012: 20-21). Pandangan ini terkesan naif. Posisi tersebut berjalan dengan turunan diplomasi ekonomi - merupakan agenda yang sensitive sebab menyangkut realitas rasonal. Negara berperang preferensi, kalaupun preferensi diantara kedua negara relatif tetap, negara superior berupaya memaksimalkan utilitasnya (Woolcock, 2013: 28).

Selanjutnya, pola kekuasaan struktural tercipta melalui bentuk pendisiplinan yang berjangka-panjang, sebuah upaya yang menciptakan ketergantungan esok (future dependency). Sederhananya, negara hegemonik tidak lagi menggunakan dirinya untuk bertarung dalam arena ekonomi, melainkan mengajak negara berkembang untuk menyepakati perihal kerjasama yang lebih mudah dan bebas. Pendisiplinan benar-benar terjadi saat korporasi dijadikan perpanjangtangan oleh negara superior. Jelasnya, negara berperan sebagai penyedia kemudahan korporasi dengan bentuk kesepakatan dagang seperti IJEPA. Untuk melihat dengan sederhana, pada dasarnya bukan Toyota yang semakin untung, melainkan Jepang. Penguasaan pasar otomotif di Indonesia telah dikuasai oleh korporasi yang berasal dari Jepang seperti, Toyota, Daihatsu, Honda, Nissan, Datsun, Mitshubishi, Suzuki, Isuzu, Mazda, dan seterusnya. Dominasi korporasi Jepang menjadikan pesaingnya dari AS mengalami goncangan akibat semakin sulit untuk bersaing, seperti raksasa otomotif Ford menarik diri dari kompetisi pasar di Indonesia.

Terdapat tiga strategi yang dilakukan oleh korporasi otomotif Jepang dalam melawan persaingan produk non Jepang, dan ini termanifestasi di Indonesia (Yoshimatsu, 1999: 500-502). (1) Penciptaan Asian Car yang tujuannya adalah mengurangi biaya produksi sehingga dapat bersaing dengan mobil produsen lain seperti dari Korea dan AS. Selain itu, Jepang mulai menggunakan komponen lokal dan mengurangi ketergantungan impor komponen otomotif. (2) Perluasan aliansi perusahaan otomotif asal Jepang. Misalnya pada Februari 1995 Toyota, Nissan, dan Isuzu membentuk sistem komponen bersama. Pada bulan Agustus 2016, Toyota secara resmi mengakuisisi saham Daihatsu dengan tetap mempertahankan merek dagang tersebut dan berada di bawah Toyota Motor Corp (The Japan Times, 2016). Pola ini sebagai ekspansi pasar yang didesain untuk menguasai pasar mobil murah, khususnya di Indonesia. (3) Mendukung industri di kawasan ASEAN yang mana industri otomotif merupakan industri yang lemah di kawasan tersebut.

Pada dasarnya kemandirian teknologi harus mendapat legitimasi dari upaya transfer teknologi. Indonesia, Thailand, Malaysia, dan Filipina adalah empat negara 
yang sama-sama memiliki kehirauan dalam pengembangan teknologi otomotif serta produksinya. Sayangnya, dalam perpindahan teknologi secara penuh, Toyota sama sekali belum melakukan upaya penuh. Akibatnya kesepakatan IJEPA melalui MIDEC yang memuat transfer teknologi hanya sekedar wacana. Sebagai pesaing penjualan Toyota di Indonesia yaitu Daihatsu telah melakukan perpindahan teknologi pada tahun 2012. Sedangkan Thailand merupakan negara yang memiliki postur perpindahan teknologi yang paling banyak dibanding Malaysia, Indonesia dan Filipina. Tabel di bawah adalah gambaran bagaimana korporasi otomotif Jepang melakukan upaya perpindahan teknologi dan program pengembangan kapasitas pekerja pasca 2005 (Tai, 2016: 49):

Tabel 6. Perpindahan Teknologi Otomotif di ASEAN

\begin{tabular}{|c|c|c|}
\hline Tahun & Perpindahan Teknologi & Pengembangan Tenaga Kerja \\
\hline 2005 & & Toyota: Thailand \\
\hline 2006 & & $\begin{array}{l}\text { Nissan: Semua negara di } \\
\text { ASEAN }\end{array}$ \\
\hline 2007 & $\begin{array}{l}\text { - Honda: Filipina } \\
\text { - Nissan: Thailand }\end{array}$ & Honda: Malaysia \\
\hline 2008 & Mitsubishi: Malaysia & $\begin{array}{l}\text { - Nissan: Indonesia, } \\
\text { Malaysia, dan Singapura }\end{array}$ \\
\hline 2009 & & Toyota: Thailand \\
\hline 2010 & Isuzu: Thailand & Nissan: Indonesia \\
\hline 2012 & Daihatsu: Indonesia & Daihatsu: Indonesia \\
\hline 2013 & Daihatsu: Malaysia & $\begin{array}{l}\text { - Honda: Semua negara di } \\
\text { - MSEAN } \\
\text { - Sitsubishi: Filipina } \\
\text { - Toyota: Filipina } \\
\text { - Toyota: Thailand } \\
\end{array}$ \\
\hline 2014 & Mitshubishi: Thailand & $\begin{array}{l}\text { - Mitsubishi: Filipina } \\
\text { - Toyota: Indonesia }\end{array}$ \\
\hline
\end{tabular}

Sumber: ASEAN Brochures published by the JAMA

Posisi di atas memperlihatkan situasi kemandirian teknologi akan lebih ditentukan oleh Jepang. Hal ini tentu menjadi paradoks, sebab pada hakikatnya kemandirian teknologi didasarkan oleh kepentingan nasional Indonesia sendiri. Realitasnya, program MIDEC sendiri mengalami pelambatan, padahal Indonesia sudah semestinya menagih janji Jepang untuk melakukan pengembangan teknologi bersama korporasi yang digandeng, utamanya Toyota. Pelambatan MIDEC sendiri adalah hasil negosiasi Indonesia yang amat lemah. 


\section{Kesimpulan}

Diplomasi yang dilakukan antara Indonesia dan Toyota merupakan suatu bentuk diplomasi transnasional. Hal ini menerangkan bahwa bentuk kepentingan dari Jepang yang terefleksikan melalui perusahaan otomotif Jepang. Meskipun tren perdagangan yang semakin kompleks, yang acapkali disebut negara makin menghilang dalam palagan ekonomi-politik, bukan berarti aktor negara dikaburkan oleh aktor non-negara (korporasi). Bantahan tersebut, tercermin disaat adanya peranan negara yang mengawal proses peraturan dan kesepakatan kemitraan seperti IJEPA. Melalui analisa yang telah dilakukan, dapat terjawab bahwa tingkat ketergantungan Indonesia terhadap Jepang, melalui Toyota, semakin tinggi dan hal ini membuat posisi tawar Indonesia menjadi rendah di negosiasi selanjutnya.

Kesepakatan IJEPA pada realitasnya tidak menguntungkan pada Indonesia, khususnya di sektor otomotif. IJEPA yang salah satu persetujuannya adalah transfer teknologi ternyata belum maksimal diterapkan oleh Toyota di Indonesia. Transfer teknologi yang dilakukan oleh Toyota di Indonesia masih berupa transfer teknologi dalam taraf rendah. Padahal target IJEPA, yaitu menjadikan Indonesia sebagai pusat pengembangan industri manufaktur sebagai motor pembangunan kapasitas industri guna peningkatan daya saing justru belum tercapai.

Dari kesemua problem ini, sepatutnya Indonesia harus keluar dari cengkraman ketegantungan yang ada. Peta jalan baru diplomasi ekonomi Indoenesia sudah sepatutnya dimulai. Desain baru dalam diplomasi ekonomi sepatutnya mengatasi empat resiko, yaitu: resiko fiskal, resiko moneter, resiko industri dan perdagangan, dan resiko lapangan kerja. Di samping itu, Indonesia harus berbenah dalam mutu diplomasi ekonomi. Persoalan yang ditemukan ialah Kemenlu memiliki peranan yang sangat sedikit dalam penentuan sikap kerjasama perdagangan, padahal kementrian ini sudah sepatutnya menjadi corong utama bagi Indonesia dengan menerjemahkan kepentingan yang ada.

Untuk menghindari persoalan kepentingan domestik yang kadang berbeda disetiap kementrian, lembaga eksekutif sepatutnya memahami diplomasi ekonomi yang harus memberikan ownerhip yang lebih besar. Strateginya yaitu diplomasi harus memanfaatkan empat sumber daya utama; kelompok epistemik, sumber daya birokratik - sebab memiliki kekuasaan untuk menentukan standard operating procedure, sumber daya politik formal dan non-formal, terakhir - pemanfaatan sumber daya sosial dengan menyangkut prioritas-prioritas yang dibutuhkan. Langkah mendasar untuk menggapai kepentingan nasioanal dalam sektor kemandirian teknologi ialah negosiasi ulang terkait keberlangsungan kesepakatan IJEPA. 


\section{Daftar Pustaka}

Abdullah, R. (2006) Business Response to the Regional to the Regional Demands and Opportunity: A Study of Malaysian Automotive Industry. Global Issues and Challanges in Business and Economics Conference. Port Dickson: Department of Management and Marketing.

Atmawinata, A., Irianto, D., Diawati, L., \& Adlir, A. (2008) Kedalaman Struktur Industri Yang Mempunya di Pasar Global: Kajian Capacity Building Industri Manufaktur Melalui Implementasi MIDEC-IJEPA. Jakarta: Depertemen Perindustrian Republik Indonesia.

Bayne, N., \& Woolcock, S. (2011) The New Economic Diplomacy: Decision Making and Negotiation in International Economic Relations. Farnham-Burlington: Ashgate.

Bergeijk, P. V., \& Moons, S. (2007) Economic Diplomacy and Economic Security. New Frontiers for Economic Diplomacy. Lisbon: ISCSP, pp. 37-54.

Blaker, M. (1977) Japanese International Negotiating Style: Bergaining Power and Success. New York: Columbia University Press.

Dachlan, A. N. (2015) Meraba Kembali IJEPA: Indoenesia Untung atau Buntung? Jakarta: The Indonesian Institute.

Doner, R. F., \& Wad, P. (2014) Financial Crises and Automotive Industry Development in Southeast Asia. Journal of Contemporary Asia, 44(4), pp. 664-687.

Hao, Y. (2013) Some Thoughts on Deepening Economic Diplomacy. China Institute of International Studies, No. 43, November/December, pp. 114-125.

Huang, J., \& Słomczyński, K. M. (2003) The Dimensionality and Measurement of Economic Dependency. International Journal of Sociology 33(4), pp. 82-98.

Kementrian Perdagangan Republik Indonesia (2016) 10 Main and Potential Commidities (online). Tersedia dalam: <http://www.kemendag.go.id/en/ economic-profile/10-main-and-potential-commodities> [Diakses 21 April 2017]

Keohane, R. O., \& Nye, J. S. (2012) Power and Interdependence. New York: Longman.

Killian, P. M. (2012) Paradigma dan Problematika Diplomasi Ekonomi Indonesia. Global \& Strategis, 6(2), pp. 171-186.

Merdeka (2013) Kisah lobi Jepang di industri mobil RI (online). Tersedia dalam: $<$ https://www.merdeka.com/uang/kisah-lobi-jepang-di-industri-mobil-ri. html> [Diakses 21 April 2017]

Odell, J. S. (2000) Negotiating the World Economy. London: Cornell University Press.

Okano-Heijmans, M. (2013) Economic Diplomacy: Japan and the Balance of National Interests. Leiden: Maartinus Njhoff Publishers.

Rana, K. S. (2007) Economic Diplomacy: Experience of Developing Countries. In N. Bayne, \& S. Woolcock, The New Economic Diplomacy: Decision-Making and Negotiations in Inter-national Economic Relations. Hampshire: Ashgate Publishing, pp. 204-207.

Rashid, H. (2005) Economic Diplomacy in South Asia (online). Tersedia 
dalam: <https://crawford.anu.edu.au/acde/asarc/pdf/papers/conference/ CONF2005_04.pdf> [Diakses 21 April 2017]

Saner, R., \& Yiu, L. (2003) International Economic Diplomacy: Mutations in Postmodern Times. The Hague: Netherlands Institute of International Relations Clingendael.

Setiawan, S. (2012) Analisis Dampak IJEPA terhadap Indonesia dan Jepang. Jurnal Ilmiah Ekonomi Bisnis. 17(2), pp. 99-112.

Strange, S. (2004) States and Markets. London: Continuum.

Tai, W.-P. (2016) The Political Economy of the Automobile Industry in ASEAN: A Cross-Country Comparasion. Journal of ASEAN Studies, 4(1), pp. 34-60.

Tai, W.-P., \& Ku, S. C. (2013) State and Industrial Policy: Comparative Political Economic Analaysis of Automotive Industrial Policies In Malaysia dan Thailand. Journal of ASEAN Studies, 1(1), pp. 55-82.

The Japan Times (2016) Toyota to make Daihatsu wholly owned subsidiary in August (online). Tersedia dalam: <https://www.japantimes.co.jp/news/2016/01/29/ business/corporate-business/toyota-to-make-daihatsu-wholly-ownedsubsidiary-in-august/\#.WeD0bPm0PIU.> [Diakses 29 Januari 2016]

Toyota Motor Manufacturing Indonesia (2015) Info Umum TMMIN (online). Tersedia dalam: <http://www.toyotaindonesiamanufacturing.co.id/fact-andfigure/corporate-fact.> [Diakses 29April 2015]

Viotti, P. R., \& Kauppi, M. V. (2012) International Relations Theory (Fifth Edition). New York: Longman Pearson.

Wallerstein, I. (2005) The Capitalist World Economy. In A. Linklater, \& S. Burchill, Theries of International Relations (Third Edition). New York: Palgrave Macmillan.

Wie, T. K. (2005) The Major Channels of International Technology Transfer to Indonesia: An Assessment. Journal of the Asia Pacific Economy, 10(2), pp. 214-236.

Woolcock, S. (2013) Factors Shaping Economic Diplomacy: An Analytical Toolkit. In N. Bayne, \& S. Woolcock, The New Economic Diplomacy: Decision Making and Negotiations in International Economic Relations. Farnham: Ashgate, pp. 28-29.

Yoshimatsu, H. (1999) The State, MNCs, and the Car Industry in ASEAN. Journal of Contemporary Asia, 29(4), pp. 495-515. 